\title{
IAMJ
}

INTERNATIONAL

AYURVEDIC

MEDICAL JOURNAL

\section{A CLINICAL STUDY TO EVALUATE THE SADYO SHOOLAHARA EFFECTIVENESS OF LAGHUPANCHAMOOLA KASHAYA WITH TRIVRUTH CHOORNAM IN GRIDHRASI (SCIATICA)}

\author{
Abhijith N ${ }^{1}$, Ravindra Bhat K ${ }^{2}$, Waheeda Banu ${ }^{3}$ \\ ${ }^{1}$ PG Scholar, Department of P.G studies in Kayachikitsa, Karnataka Ayurveda Medical College and Hospital, \\ Mangalore, D.K District, Karnataka, India \\ ${ }^{2}$ Professor, Department of P.G studies in Kayachikitsa, Karnataka Ayurveda Medical College and Hospital, Man- \\ galore, D.K District, Karnataka, India \\ ${ }^{3}$ Professor and Head of the Department, Department of P.G studies in Kayachikitsa, Karnataka Ayurveda Medical \\ College and Hospital, Mangalore, D.K District, Karnataka, India
}

Corresponding Author: kedaramabhijith@gmail.com

\section{https://doi.org/10.46607/iamj1809082021}

(Published Online: August 2021)

Open Access

(C) International Ayurvedic Medical Journal, India 2021

Article Received: 15/08//2021 - Peer Reviewed: 16/08/2021 - Accepted for Publication: 16/08/2021

\section{Check for updates}

\section{ABSTRACT}

Gridhrasi is one among Vataja nanatmaja Vikara characterised by Sthabdhata, Ruk, Toda which radiates from buttock region, lumbar region, thigh, knee, calf muscles and legs. Gridhrasi is of two types viz Vataja and Vata Kaphaja Gridhrasi. Vataja Gridhrasi is characterized by severe pain and Vata Kaphaja Gridhrasi has symptoms viz Tandra, Gaurava and Aruchi. The signs and symptoms of Gridhrasi can be correlated to sciatica of modern medicine. Sciatica is characterized by constant aching pain felt in lumbar region which may radiate to the buttock, thigh, calf and foot and pain is experienced along the sciatic nerve pathway. It was a clinical study with a pre and post design in 30 patients who were diagnosed with Gridhrasi. After examination Laghupanchamoola Kashaya with trivruth choornam was given for 7 days. The assessment criteria were noted before and after treatment and on follow-up. Among the subjective and objective parameters, in the Overall effect of treatment in gridhrasi, out of 30 patients in this study, 15 patients (50\%) got Mild effectiveness in shoola, and 15 patients (50\%) got Moder- 
ate effectiveness in shoola. The overall effect of the treatment was $30.19 \%$. Hence it can be concluded that Laghupanchamoola Kashaya with trivruth choornam is having mild improvement on symptoms of Gridhrasi and shows the long-lasting result.

Keywords: Gridhrasi, Sciatica, Laghupanchamoola Kashaya, Trivruth choornam

\section{INTRODUCTION}

Gridhrasi is one among Vataja Nanatmaja Vikaral characterized by pain that radiates along kati, prushta (hip), uru (thigh), janu (knee), jangha\& pada (leg and foot $)^{2}$. It is classified as Vataja and Vata Kapha$j a^{3,4,5}$ variety based on the dominance of a particular Dosha ${ }^{6,7,8}$. In modern parlance, Gridhrasi looks similar to Sciatica. Sciatica is a term that refers to pain that radiates along the sciatic nerve and is typically felt in the buttock, down the leg, and possibly to foot $^{9}$. Sciatica is a relatively common condition with a lifetime incidence varying from $13 \%$ to $40 \%{ }^{10}$. The prevalence of sciatic symptoms reported in the literature varies considerably ranging from $1.6 \%$ in the general population to $43 \%$ in a selected working population. Although the prognosis is good in most patients, a substantial proportion (up to $30 \%$ ) continues to have pain for 1 year or longer. In the Modern system of medicine, administration of NSAIDS (NonSteroidal Anti-Inflammatory Drugs), analgesics, muscle relaxants etc; gives temporary relief and their long-term use can produce toxic effects to the different systems of the body. As the last resort, surgical procedures are carried out, which are quite expensive and need hospitalization and also cause adverse effects like, bowel and bladder incontinence. Today there is a need to find a drug to manage acute pain which is cost-effective, easily available and has excellent results with zero side effects. Here in this study Laghupanchamoola ${ }^{11}$ (Brihati - Solanum Indicum, Kantakari - Solanum xanthocarpum, Shalaparni - Desmodium gangeticum, Prishnaparni Uraria picta, Gokshura -Tribulus Terrestris) was utilized in the form of kwatha along with trivruth choorna (Operculina turpethum) as prakshepaka dravya to find out its efficacy. The properties are kashaya- tikta- madhura in rasa as having Vataghna, Pittaghna, Brimhana and Bala vardhana karma. In both Ashtanga Sangraha and Ashtanga Hridaya, the five drugs of Laghupanchamoola are grouped under Hrisvapanchamoola and its properties are Madhura Rasa, Madhura Vipaka, neither Atishita nor Atiushna and Sarva doshahara by its action i.e., neither too hot nor too cold in potency and pacify all the three doshas.

\section{AIM AND OBJECTIVES}

To evaluate the effect of Laghupanchamoola kashaya with Trivruth choornam as prakshepa dravya in the management of Sadyoshoola in Gridhrasi (Sciatica).

\section{METHODOLOGY}

\section{Method of collection of data}

A minimum of 30 patients fulfilling the diagnostic and inclusion criteria of either gender was selected for the clinical study.

\section{Diagnostic criteria:}

The patient who presented with signs and symptoms of Gridhrasi, both vataja and vatakaphaja

- Ruk (Pain) on Sphik, Kati, Prishta, Uru, Janu, Jangha and Pada

Associated with one or multiplicity of these:

- Toda (Pricking pain)

- Straight Leg Raising Test positive Inclusion criteria:

- Patients who fulfilled the diagnostic criteria.

- Patients of age limit between 20 - 70 years, irrespective of gender and socio-economic status

\section{Exclusion criteria:}

- Patients with systemic diseases

- Traumatic lesion in lumbo-sacral region

- Infective, Neoplastic conditions of the spine

- Pregnancy and lactation 


\section{PROCEDURE AND DESIGN OF THE STUDY}

\section{Plan of treatment}

Included patients were treated as follows:

Laghupanchamoola kwatha with two divided doses of $48 \mathrm{ml}$ with $6 \mathrm{gm}$ of trivruth choornam each before food in the morning \& evening for 7 days.

\section{Study duration}

The total duration of the study was 7 days of active intervention with periodical observations done once in 4 days.

\section{Assessment criteria}

Subjective Parameters

- Ruk (pain)

- Toda (pricking pain)

\section{ObjectiveParameters}

- Straight Leg Raising Test

- VAS scale (Visual Analogue Scale)

Investigations:

- Blood Routine Examination (Complete Blood Count, Serum Creatinine, Serum Uric acid, RA factor, Random Blood Sugar).

- Urine routine examination (Albumin, sugar, Microscopic).

- Radiological examination of the lumbo sacral spine in anterior-posterior and lateral position.
- $\mathrm{MRI}$

\section{Assessment of results}

- Statistical analysis was done using SPSS package, version 22

- All the qualitative variables were summarized using frequency and percentages

- The quantitative variables were summarized using mean and standard deviation, median and interquartile range $(\mathrm{Q} 3, \mathrm{Q} 1)$

- Data were analyzed using normal distribution then performing parametric and non-parametric tests

- Since all subjective variables were qualitative data, the assessment was done by paired t-test.

The corresponding p-value was noted and obtained results were interpreted as follows:

- For $\mathrm{p}$ value $>0.05$ - interpreted as no significant.

- For $p$ value $<0.05$ - interpreted as significant.

\section{OBSERVATIONS AND RESULTS}

The observations give a detailed descriptive statistical analysis about all the 30 patients suffering from Gridhrasi according to their Age, Sex, Religion, Education, Socioeconomic status, Marital status, Occupation, Duration of illness, Ahara, Prakrithi.

RESULTS

Statistical analysis of Subjective and Objective parameters

\begin{tabular}{|c|c|c|c|c|c|c|c|c|c|}
\hline \multirow[t]{2}{*}{ Group } & \multicolumn{4}{|c|}{ Mean score } & \multirow[t]{2}{*}{$\%$} & \multirow[t]{2}{*}{ S.D $( \pm)$} & \multirow[t]{2}{*}{ S.E ( \pm$)$} & \multirow[t]{2}{*}{ t value } & \multirow[t]{2}{*}{ p-value } \\
\hline & BT & & & BT-AT & & & & & \\
\hline \multirow[t]{2}{*}{ Ruk } & \multirow{2}{*}{5.97} & AT & 4.83 & 1.14 & 18.99 & 0.776 & 0.144 & 3.43 & $<0.05$ \\
\hline & & $\mathrm{AF}$ & 3.83 & 2.14 & 35.75 & 1.042 & 0.193 & 5.92 & $<0.05$ \\
\hline \multirow[t]{2}{*}{ Toda } & \multirow[t]{2}{*}{1.77} & AT & 1.37 & 0.40 & 22.64 & 0.675 & 0.125 & 1.60 & $<0.05$ \\
\hline & & $\mathrm{AF}$ & 1.00 & 0.77 & 43.40 & 0.728 & 0.135 & 3.16 & $<0.05$ \\
\hline \multirow{2}{*}{$\begin{array}{l}\text { SLR Active Right } \\
\text { Leg }\end{array}$} & \multirow[t]{2}{*}{2.20} & AT & 1.80 & 0.40 & 18.18 & 0.563 & 0.105 & 1.71 & $<0.05$ \\
\hline & & $\mathrm{AF}$ & 1.70 & 0.50 & 22.73 & 0.572 & 0.106 & 2.20 & $<0.05$ \\
\hline \multirow[t]{2}{*}{ SLR Active Left Leg } & \multirow[t]{2}{*}{1.63} & AT & 1.57 & 0.03 & 4.08 & 0.254 & 0.047 & 0.32 & $>0.05$ \\
\hline & & $\mathrm{AF}$ & 1.40 & 0.23 & 14.29 & 0.504 & 0.094 & 1.18 & $>0.05$ \\
\hline \multirow{2}{*}{$\begin{array}{l}\text { SLR Passive Right } \\
\text { Leg }\end{array}$} & \multirow[t]{2}{*}{2.07} & AT & 1.73 & 0.34 & 16.13 & 0.547 & 0.102 & 1.56 & $<0.05$ \\
\hline & & $\mathrm{AF}$ & 1.50 & 0.57 & 27.42 & 0.626 & 0.116 & 2.81 & $<0.05$ \\
\hline \multirow{2}{*}{$\begin{array}{l}\text { SLR Passive Left } \\
\text { Leg }\end{array}$} & \multirow[t]{2}{*}{1.60} & AT & 1.47 & 0.13 & 8.33 & 0.346 & 0.064 & 0.69 & $>0.05$ \\
\hline & & $\mathrm{AF}$ & 1.27 & 0.33 & 20.83 & 0.547 & 0.102 & 1.96 & $<0.05$ \\
\hline
\end{tabular}


The overall effect of treatment

OVERALL EFFECT OF TREATMENT

Grading

No Improvement

Mild Improvement

Moderate Improvement

Marked Improvement

Complete Remission

In the Overall effect of treatment in gridhrasi, out of 30 patients in this study, 15 patients $(50 \%)$ got Mild effectiveness in shoola, and 15 patients $(50 \%)$ got Moderate effectiveness in shoola. The overall effect of the treatment is $30.19 \%$.

\section{DISCUSSION}

\section{Discussion on Disease}

Gridhrasi was known since the Samhita kala which is caused due to the vitiation of Vatadosha. The causes of Gridhrasi are not described in the Classics, but the factors about Vatavyadhi are the nidanas.

Rukshaaaharasevana, Vegadharana, Atiyaanadi viharas, Agantuja and shokadi manasika hetus are responsible for the provocation of Vatadosha which leads to Vatavyadhi like Gridhrasi. Among the 5 types of vata, Apana vata and Vyana vata play an important role in the causation of disease. The vitiated vata afflicts the snayu and kandara resulting in difficulty in walking and restricted movement of the spine. Occasionally Kaphaanubandhatva may be seen with additional symptoms of tandra, gaurava and aruchi.

Sciatica or Sciatica Syndrome - a condition described in modern medicine resembles Gridhrasi. In Sciatica, there is pain along with the distribution of the Sciatic nerve which begins in the lower back and radiates through the posterior aspect of the thigh and calf and to the outer border of the foot. This illness is named so because of its complexing symptoms as well as etiological factors with numbness and paranesthesia in lower extremities favours the diagnosis. Herniation and degenerative changes in the disc are the most common causes. There is often a history of trauma as twisting of the spine lifting heavy weights or expo-

\begin{tabular}{|l|l|}
\hline Relief in Percentage & Relief in Patients \\
\hline $0 \%$ & 0 \\
\hline $1-30 \%$ & 15 \\
\hline $31-60 \%$ & 15 \\
\hline $61-99 \%$ & 0 \\
\hline $100 \%$ & 0 \\
\hline
\end{tabular}

sure to cold. The disability caused by the disease hampers day to day activity of the patients and make the patient crippled.

There is no need to state that modern medical treatment has its limitation in managing this type of disease. Modern medical treatment is either conservative or surgical and is highly symptomatic and with troublesome side effects. This suggests a special need for ayurvedic management for this type of condition.

For all Vatavyadhis, the principal line of treatment is Snehana, Swedana and Mrudushodhana. Snayu and Rakta are involved as Dushya. Kandara of parshni and pratyanguli have been stated as adhishtana of disease Gridhrasi. Agni karma and Siravyadha are the chief lines of treatment. Mrudu shodhana in the form of Basti forms the major treatment of Gridhrasi. The Shamanaushadhis are also having some role in the management of symptoms of Gridhrasi.

\section{DISCUSSION ON RESULTS:}

In the Overall effect of treatment in Gridhrasi, out of 30 patients in this study, 15 patients $(50 \%)$ got Mild Improvement and 15 patients (50\%) got Moderate Improvement. The overall effect of the treatment was $30.19 \%$. The obtained results were to be considered as insignificant if $\mathrm{P}>0.05$, significant if $\mathrm{P}<0.05$.

\section{Probable mode of action of Bruhatyadi}

\section{kashayam and Trivruth choornam:}

The ingredients of Bruhatyadi kashaya are Brihati, Kantakari, Gokshura, Shalaparni and Prisnaparni all these drugs are ushnavirya pradhana which is the opposite quality of vata and at the same time due to tikta rasa suppresses kapha. Trivruth due to its ruksha and tikshna guna pacifies the vata, at the same time due to its katu rasa it will suppress the kapha. Thus, Bruhatyadi kashaya with trivruth choorna has va- 
takaphahara karma and also due to its deepana pachana kriya helps remove the ama and thereby remove the srotoavarodha and thus effective in treating both vataja and vataka phaja type of Gridhrasi.

\section{CONCLUSION}

At the end of the study, the following conclusions were drawn based on observations made, results achieved and after thorough discussions in the present context, Laghupanchamoola kwatha with Trivruth choornam was having more effect on symptoms of Gridhrasi and shows the long-lasting result. In the Overall effect of treatment in gridhrasi, out of 30 patients in this study, 15 patients (50\%) got Mild effectiveness in shoola, and 15 patients $(50 \%)$ got Moderate effectiveness in shoola. The overall effect of the treatment was $30.19 \%$. Thus, the alternate hypothesis H1 is accepted i.e. There was a significant effect of Laghupanchamoola kashaya with Trivruth choornam as prakshepa dravya in the management of Sadyoshoola in Gridhrasi (sciatica).

\section{REFERENCES}

1. Acharya Jadhavji Trikamji, editor, ( $2^{\text {nd }}$ ed). Commentary Ayurveda deepika of Chakrapanidatta on Charakasamhita of Agnivesha, Sutra stana; Maharogadhyaya: Chapter 20, Verse 11, Varanasi: Chaukhambaorientalia, 2015; p-113.

2. Acharya JT, editor, ( $2^{\text {nd }}$ ed). Commentary Nibandhasangraha of Dalhanacharya on Sushruthasamhitha of Sushrutha, Nidaastana; Vatavyadhinidaam: Chapter 1, Verse 74, Varanasi: Chaukhambaorientalia, 2014; p- 268.

3. Acharya JT, editor, ( $2^{\text {nd }}$ ed). Commentary Nibandhasangraha of Dalhanacharya on Sushruthasamhitha of Sushrutha, Chikitsastana; MahavatavyadhiChikitsitam: Chapter 5, Verse 23, Varanasi: Chaukhambaorientalia, 2014; p- 428.

4. Sharma Shivaprasad, editor ( $3^{\text {rd }}$ ed). Commentary Shashileka of on Astangasangraha of VriddhaVagbhata; Sutrasthana; Vatavyadhichikitsitam; Chapter 20, Verse 15, Varanasi; Chaukhamba Sanskrit series office, 2012; p-158.

5. Sharma Shivaprasad, editor ( $3^{\text {rd }}$ ed). Commentary Shashileka of on Astangasangraha of VriddhaVagbhata; Nidanasthana; VatavyadhiNidana;
Chapter 15, Verse 36, Varanasi; Chaukhamba Sanskrit series office, 2012; p-416.

6. Vaidya BHP, editor $\left(10^{\text {th }}\right.$ ed). Commentary Sarvangasundara of Arunadatta and Ayurvedarasayana of Hemadri on Astangahrdayam of Vagbhata; Nidanasthana; VatavyadhiNidana; Chapter 15, Verse 54, Varanasi; Chaukhambaorientalia, 2014; p-535.

7. Sharma PV, editor. Bhelasamhita of Bhela, Chikitsastana; vatavyadhichikitsa; Chapter 24, Verse 32-33, Varanasi; ChaukhambaVishwabharathi, 2010; p-452-453.

8. Acharya Jadhavji Trikamji, editor, ( $2^{\text {nd }}$ ed). Commentary Ayurveda deepika of Chakrapanidatta on Charakasamhita of Agnivesha, ChikitsaSthana; Vatavyadhichikitsitam: Chapter 28, Verse 56-57, Varanasi: Chaukhambaorientalia, 2015; p-619.

9. Sir Stanley Davidson, Davidson's Principles and Practice of Medicine, editors Nicholas A Boon, Nicki R Colledge, Brian R Walker, John A.A Hunter, published by Churchill Livingstone Elsevier, 20th Edition (2006), 26th chapter, p. 1242.

10. https://en.wikipedia.org/wiki/Sciatica

11. Yogarathnakara, edited and translated by Suresh Babu, Chaukhambakrishnadas academy Varanasi, $2^{\text {nd }}$ edition 2011; pg-623

\section{Source of Support: Nil Conflict of Interest: None Declared}

How to cite this URL: Abhijith $\mathrm{N}$ et al: A Clinical Study To Evaluate The Sadyo Shoolahara Effectiveness Of Laghupanchamoola Kashaya With Trivruth Choornam In Gridhrasi (Sciatica). International Ayurvedic Medical Journal \{online\} 2021 \{cited August 2021\} Available from: http://www.iamj.in/posts/images/upload/1717_1721.pdf 